\title{
Must We Kill to Conserve?
}

\author{
Some Ethical and Technical Problems of Wildlife \\ Conservation \\ By F. Fraser Darling
}

In the last hundred years civilised man has begun to question the morality and wisdom of subjugating all wild country and its wildlife. The result has been the establishment of sanctuaries and reserves. But now man is beginning to see that absolute sanctuary may not be the complete answer to the problem. What happens when the protected animals, like the elephants in the Murchison Falls Park in Uganda, destroy their sanctuary? Dr. Darling, well-known ecologist, vice-president of the Conservation Foundation, and a past member of the FPS Council, shows the inevitability of the answer. This occasional paper of the Foundation was the substance of his address at the annual general meeting in the spring of the Berks, Bucks and Oxon Naturalists' Trust in Reading.

WYHEN the man in the street reads of officially authorised slaughters of seals and elks and elephants, just as a changing ethos is apparent in the western nations towards caring for wild animals and setting aside places where they may live in peace, he may well scratch his head and wonder if biologists have gone wild or have misled him flagrantly.

One of the most significant changes in the outlook on natural history in recent years has been apprehension of the fact that animals and plants do not live alone; they exist in their environment, which is not merely physical or climatic, but biotic and social. I say apprehend, because we cannot say as yet that we comprehend. To gain understanding of the complex relationships of organisms to each other and between members of the same species and group is part of the aim of the science of ecology. Conservation of wild life today centres primarily on maintenance of the habitat as a satisfying living place for the animals and plants within it. We tend to imagine a golden age or state of nature in which checks and balances operated more or less perfectly to maintain a status quo of beautiful variety. Broadly there have been and are such situations, but nature is nevertheless dynamic and change occurs. Mankind may be a member species of a biological community of animals and plants, especially if he is a primitive hunter-foodgatherer being denied the luxury of developed gregariousness. Man is not necessarily vile, but in these days he does make biological communities unstable. He, and all other creatures, are to some extent co-operating in maintenance of some habitats, though in general there is no consciousness of co-operation. Evolution is a story of this unconscious co-operation as much as of competition. Survival of the fittest may be in capacity to co-operate as well as to elbow a way through.

Civilised man, impinging on the vast wilderness of the planet, increasing 
his own numbers and bearing mercilessly on some of the plant and animal associations of the world has, within the last century, begun to question the morality and the wisdom of utter subjugation of wilderness and its denizens. The increasing tempo of destruction has brought us now to an acute awareness, in which I believe the vast majority of us suffer morally and emotionally. Orthodox religion offers us curiously little comfort or guidance. Our greatest response so far, a right and honourable one, has been to establish sanctuaries and reserves. Sanctuaries were the immediate uncritical emotional response, thinking in terms of saving beautiful animals, and we also wished to save beautiful wild scenery. It was from this point that the national park movement grew in the United States. A more scientific and critical response, but none the less moral, has been the establishment of Wildlife Refuges in the United States, and National Nature Reserves in the United Kingdom under the care and management of the Nature Conservancy. Such areas have been chosen on scientific criteria and are under management. Sanctuaries for particular species, and the earlier national parks of the world, were the first move, and no one doubted their efficacy; but understanding of population dynamics and habitat conservation was almost non-existent. It is only now we find that inviolable sanctuaries are not the answer to perpetuation of a species or a biological community, and that management of a reserve in which species and habitats are to be perpetuated is a task of much technical difficulty.

\section{Damage Done By Elk}

How disturbing it has been to establish a national park of some thousands of square miles in wilderness country and then find it is too small to be left to take its own course! This is what has happened in the first national park in the world, Yellowstone, Wyoming, established in 1872, and about 3,200 square miles in extent. Indeed, it is to the United States that the world owes the generous idea of such places. The wolf has been wiped out because this remarkable animal cannot be tolerated in ranching country; coyotes persist and are not harried in the park but they migrate northwards into Montana and are shot or poisoned. Cougars or pumas also move out and are lost; and though Yellowstone has a good population of grizzly bears, some of them move down northwards and become trophies. The herds of wapiti, called elk in Wyoming, did not move great distances beyond the park boundaries and, in the absence of sufficient checks, increased much beyond the carrying capacity of the land. I was there in 1950 , taking special note of the deterioration of the range, particularly of the aspen groves. Since then, the population of elk has been approximately halved and I examined the range again last summer. There is some immediate repair, but remembering those groves of aspen I was shocked to find many of them gone, a consequence irreparable in a century or more.

There was a highly emotional battle in the United States between firm upholders of the idea of sanctuary and the National Park Service which had to deal with the problem, advised by wildlife managers who are as devoted to animals as their opponents, but who have studied carrying capacity and composition of the habitat in detail and realise that the welfare of the species is more important than the survival of individuals ; 
further, the fate of the elk is not the only matter at stake: the whole biological community and the habitats of each member species are concerned.

Fifteen years ago and until five years ago I was active in urging a reduction in the numbers of red deer in Scotland, an attitude which many people could not understand in someone supposed to be an upholder of conservation. The Red Deer Commission is now in operation and some reduction is being made. The immediate benefit may be to farmers whose land lies within the winter spill-over of the deer forests, but those of us who see the age-classes of the deer stocks getting better proportioned know that the red deer are also benefiting directly from the pruning.

\section{Sanctuary is Not Enough}

The staggering build-up of the elephant population in the Tsavo National Park in Kenya and eastwards from there, has resulted in severe punishment of the habitat over several thousand square miles. The elephants are having a thin time, but they are better off than some other animals, notably the rhinoceros, which do not or cannot move out. I saw some of the 200 or more rhinoceros which starved to death three years ago and it was an altogether upsetting experience. Our early uncritical generous notion of sanctuary had not been good enough. Man is constricting the range of the elephant in Africa and the areas being left to this great, wise, lovable creature must be managed for its benefit by studying population in relation to carrying capacity and condition of the habitat. The tragedy in the Tsavo Park is imminent also in the Murchison Falls Park in Uganda. Those of us who truly love the elephant and who are deeply concerned for its survival, should be ready to reduce the population in certain areas in ways which are going to hurt us emotionally. It would be unthinkable to harass large migrating groups in the dry season, killing some adults and making the herds hysterical. We must be prepared to work in the wet season when family groups are small and to extirpate completely a family group so that disturbance is minimal and none lives to tell the tale for, of course, elephants are able to communicate factually as well as we can, and I cannot see that their suffering is less than ours. The task is easier with less intelligent and more phlegmatic animals like the hippopotamus. These animals damaged their habitat so severely in the Queen Elizabeth National Park in Uganda that the notion of sanctuary had to be laid aside. After a considerable initial reduction, an annual removal of 500 hippopotami is now attempted. Rehabilitation of the riverside habitat has been fairly rapid.

\section{Grey Seals Without a Predator}

The Commissioners of the River Tweed asked me to study the grey seal problem (as they saw it) in 1939-40, in relation to the salmon fishery. There were then 300-400 seals on the Farne Islands, Northumberland, as against eighty earlier in the century. I saw the grey seals catching and eating salmon in the river mouth off the end of Berwick breakwater, but the fishermen did not mind this toll so much as damage to the nets and to fish in the nets. Such damage also occurs far up the east coast of Scotland. It is unfortunate that the Farnes colony of seals, depending on the island 
beaches for breeding, should be so near this famous salmon river. It would be quite foolish to suggest that the seals subsist principally on the salmon; this fish must represent a very small fraction of their diet, but if the colony of seals is to be allowed complete sanctuary, which it had not enjoyed for thousands of years until this century, the increasing population is certainly going to effect a larger gross damage. The present population of seals runs into some thousands because man voluntarily ceased to be a predator on them, and quite apart from the open question of whether man as a rival predator on the salmon has any right thereby to reduce the number of seals, it is pertinent to inquire into the welfare of the seals fast multiplying on a limited nursery ground. I advised in 1940 that the seals haunting the mouth of the Tweed at the time of the fish runs should be hunted actively by the Commissioners' staff, but there was no justification for reduction on the Farne Islands. Nor was there justification; but there is, probably, now. The removal of 350 seal calves in 1963 will not have endangered the stock and the action may well have helped it. I have visited several of the largest seal nurseries off the Scottish coasts and have been sad at the conditions apparent when there is over-crowding. Calves are crushed, many get ophthalmia and there is undue fighting among the cows. There is certainly an optimum density which is desirable, but optimum density is not maximum density.

\section{Disturbance Can Be Valuable}

Here again, a more effective reduction of population could be made by killing half as many gravid cows as the calves killed in 1963, but it would be much harder work, possibly more disturbing to the stock, and harder on our feelings, which are not adjusted to the idea of killing mothers-to-be of a species we desire so earnestly to conserve. Some years ago, observing the tendency of American white-tailed deer, and to a lesser extent Scottish red deer, to "yard " or hang about one area in winter, I had the idea that some disturbance was good for closely gregarious animals. Wolves prevent "yarding" in deer and thereby help to conserve habitat. Man, in the absence of wolves, must accept the task of conscious management. I now feel that a limited amount of disturbance of the grey seals will do no harm to them as a stock because they will spread their breeding over more of the possible sites, rather than overcrowding on a few.

We are faced with an ethical problem as well as the scientific and technical one, and it would be cowardly to ignore it and deceive ourselves by holding inflexibly to the idea of sanctuary. We cannot be Jains stooping and peering before each step lest we crush worm or beetle, because we know our feet must crush smaller life than our eyes can see, yet we should be ready to admit that animals exist in their own right and not by our permission. Surely it is no lack of respect for life, but high courage, to face the necessity of killing in order to conserve when the situation is so contrived that the creatures cannot be allowed their total ancient ranges ? The educational task towards general acceptance of such a view is immense, involving a scholarly philosophical discipline in getting our minds clearer. The technical task is to learn how to implement it with least suffering to the individuals killed and to the collective memory of the species. 